\title{
Histopathological and Bacteriological Study on Hepatic Abscesses of Herrik Sheep
}

Aliasghar Tehrani ${ }^{1}$, Javad Javanbakht ${ }^{2 *}$, Mehdi Agha Mohammad Hassan ${ }^{3}$, Mohammad Zamani ${ }^{2}$, Mojtaba Rajabian ${ }^{4}$, Hamid Akbari ${ }^{5}$ and Radmer Shafei ${ }^{4}$

${ }^{1}$ Department of Pathology, Faculty of Veterinary Medicine, Urmia University, Urmia, Iran

${ }^{2}$ Department of Pathology, Faculty of Veterinary Medicine, Tehran University, Tehran, Iran

${ }^{3}$ Department of Clinical Sciences, Faculty of Veterinary Medicine, Tehran University, Tehran, Iran

${ }^{4}$ Graduate Faculty of Veterinary Medicine, Tehran University, Tehran, Iran

${ }^{5}$ Department of Clinical Sciences, Faculty of Veterinary Medicine, Urmia University, Urmia, Iran

\begin{abstract}
Background: Liver abscesses constitute a major economic problem and there exists very less information in association with liver abscesses in ovine. Although studies in several countries have reported on the incidence of ovine hepatic abscesses at abattoirs, few surveys have identified the etiology and pathological characteristics of these abscesses.
\end{abstract}

Aim: The aim of this research is histopathological and bacteriological study on hepatic abscesses of Herrik sheep.

Methods: The lesion specimens of 5000 condemned sheep livers were collected from four provinces (Western Azerbaijan, Eastern Azerbaijan, Kordestan and Kermanshah) abattoirs for bacteriological (aerobic and anaerobic) culture and pathologic examination.

Results: Grossly, 230 liver abscesses (4.6\%) found that 110 cases were in female sheep $(47.8 \%)$ and 120 cases were in male sheep $(52.1 \%)$. Most of the abscesses were found in diaphragmatic surface $(23.48 \%)$, visceral surface $(22.1 \%)$ and right lobes $(21.3 \%)$ of the livers. Regarding the presence of abscesses, there was no significant difference between sexes, lobes and surfaces of livers $(p>0.05)$. The following bacteria were isolated: from 120 of which, Corynebacterium (52.4\%) was isolated, and from 26 of which, Pasteurella (11.3\%), from 25 of which, Escherichia coli (11.1\%), from 16 of which, Proteus (7.2\%), from 16 of which, Pseudomonas aeruginosa (7.2\%), from 13 of which, streptococcus $(5.5 \%)$, from 12 of which, staphylococcus $(5.3 \%)$ were isolated and no bacteria were isolated from the remaining 2 liver abscesses.

Conclusions: Our study suggested that Corynebacterium pseudotuberculosis is the most prevalent bacterium incriminated for hepatic abscesses in sheep. Histologically, these lesions had a core of caseous necrosis, encircled by a zone of necrotic phagocytic cells and bacteria with cellular characteristics of Corynebacterium pseudotuberculosis and a connective tissue capsule with calcification.

Keywords: Liver; Abscess; Bacteriology; Histopathology; Abattoir

\section{Introduction}

Liver abscesses constitute a major economic problem and there exists very less information in association with liver abscesses in sheep $[1,2]$. The etiology and pathogenesis of hepatic abscesses in sheep has been proposed to be similar to those of sheep hepatic abscesses $[1,3,4]$. The etiology of hepatic abscesses in sheep often the association between the occurrence of hepatic lesions and rumenitis has been reported previously [5]. Cattle hepatic abscesses usually occurs secondary to other bacterial infections in the various organs of the body [1]. In lambs, septicemia or propagation of an umbilical vein infection can cause hepatic abscesses [6] and usually occur as a result of chronic rumenitis in cattle, but they may be seen rarely in sheep [7,8]. In most cases; however, hepatic abscesses are a circumstantial findings but rarely weight loss, anorexia, depression and reduction in production (grown, milk) may occur and usually found in the hepatic at the time of slaughter or necropsy as well as encapsulated with thick fibrotic walls [9]. In the USA about $3 \%$ of the sheep slaughtered annually have liver abscesses and in another study, about $16.4 \%$ has been declared in Texas [10]. In another study, about $8.6 \%$ of 576 slaughtered sheep has been announced in Ahvaz (South West of Iran) [11]. Fusobacterium necrophorum was considered to be part of the ordinary intestinal flora, has been involved as primary cause of hepatic abscesses in cattle. Bacterial agents such as Streptococcus, Staphylococcus, Trueperella pyogenes, Bacteroides spp. and members of the Enterobacteriaceae often in partnership with F. necrophorum or are found alone [12-14]. Araghi-Sooreh and Firuzi [15] studied microorganisms associated with abscesses in sheep and goats in Iran, and reported that out of a total of 120 abscesses, six hepatic abscesses were found in sheep and only one in a goat. The isolated bacteria were Corynebacterium pseudotuberculosis (3 cases), Trueperella pyogenes (2 cases), Escherichia coli (2 cases), Fusobacterium necrophorum (1 case), Streptococcus spp. (1 case), and Pseudomonas spp. (1 case) [15].The present study was performed to evaluate the prevalence of liver abscesses in sheep and to obtain an explicit picture of the bacteriological and pathological features associated with their occurrences.

*Corresponding author: Dr. Javad Javanbakht, Department of Pathology, Faculty of Veterinary Medicine, Tehran University, Tehran, Iran; E-mail: javadjavanbakht@ut.ac.ir

Received August 01, 2012; Accepted August 02, 2012; Published September 05, 2012

Citation: Tehrani A, Javanbakht J, Hassan MAM, Zamani M, Rajabian M, et al. (2012) Histopathological and Bacteriological Study on Hepatic Abscesses of Herrik Sheep . J Med Microb Diagn 1:115. doi:10.4172/2161-0703.1000115

Copyright: (C) 2012 Tehrani A, et al. This is an open-access article distributed under the terms of the Creative Commons Attribution License, which permits unrestricted use, distribution, and reproduction in any medium, provided the original author and source are credited. 
Citation: Tehrani A, Javanbakht J, Hassan MAM, Zamani M, Rajabian M, et al. (2012) Histopathological and Bacteriological Study on Hepatic Abscesses of Herrik Sheep . J Med Microb Diagn 1:115. doi:10.4172/2161-0703.1000115

Page 2 of 4

\section{Materials and Methods}

\section{Study district}

In the period between October 2010 to August 2011, the livers of 5000 carcasses of sheep slaughtered (of varying ages, sexes and breeds such as Ghezel, Herrick, Afshari and Makuei) at the local industrial abattoirs in (north west and west of Iran) were examined for abscesses. Assessment of the liver abscesses: Liver was examined and the number, location and size of abscesses were recorded and then sampling for bacterial culture was done.

\section{Groups and ages}

The sheep were categorized as young (day 0 to 5 months of age) or adult (animals over 5 months of age), and the gross appearance and size of each abscess were recorded, subsequently the abscesses were classified according to anatomical location in liver lobes (e.g. right, left or quadrate) as well as to surface (e.g. visceral or diaphragmatic).

\section{Species collection}

The lesion specimens were from healthy slaughtered sheeps .The specimens were collected from affected livers, and placed in sterile plastic containers and shipped to the laboratory, on ice, for bacterial culturing. Identification of aerobic and anaerobic bacterial isolates was done using standard procedures $[16,17]$.

\section{Pathological evaluation}

Multiple sections were made of the hepatic at post mortem examination. Post-mortem examination consisted of macroscopic and histopathological evaluation of tissues and organs using the techniques of Winter [18] and Jacob [10]. Fragments of liver specimens referred to histopathological evaluation with routine laboratory techniques and stained by H\&E [19].

\section{Statistical tests}

Statistical analysis is performed using Z-test and Chi-Square.

\section{Results}

Prevalence abscesses: Post-mortem examination of 5000 carcasses sheep (of the four races such as 2150 male and 2850 female) showed that $230(4.6 \%)$ exhibited hepatic abscesses.

Sex: One hundred and ten (47.8\%) abscesses in female and one hundred and twenty (52.1\%) abscesses were found in male and this shows there is no significant difference between the two sexes $(p>0.05)$ (Table 1).

Age: Out of the 230 liver abscesses examined, 45 liver abscesses in sheep under 5 month (19.5\%) and 185 other cases were observed in high 5 months $(80.5 \%)$, and these statistics indicated that there was significant differences between ages $(\mathrm{p}<0.05)($ Table 2$)$.

\section{Localization of abscesses}

Table 3 and 4 demonstrates the frequency of liver abscesses in different liver lobes and surfaces. Out of 230, the liver abscesses

\begin{tabular}{|c|l|l|l|}
\hline Male & $110(4.6)$ & $2282(95.4)$ & $2392(47.84)$ \\
Female & $120(4.6)$ & $2488(95.4)$ & $2608(52.16)$ \\
Total & $230(4.6)$ & $4770(95.4)$ & $5000(100.0)$ \\
\hline
\end{tabular}

Table 1: Frequency of liver abscesses in both sexes.

\begin{tabular}{|l|l|l|l|}
\hline Age & With abscess (\%) & Without abscess (\%) & Total (\%) \\
\hline Less than 5 months & $45(4.6)$ & $934(95.4)$ & $979(19.6)$ \\
More than 5 months & $185(4.6)$ & $3836(95.4)$ & $4021(80.4)$ \\
\hline Total & $230(4.6)$ & $4770(95.4)$ & $5000(100.0)$ \\
\hline
\end{tabular}

Table 2: Frequency of liver abscesses in different age groups.

\begin{tabular}{|l|l|l|l|l|}
\hline Location & Right lobe (\%) & Left lobe (\%) & Right and Left lobes (\%) & Total (\%) \\
\hline Frequency & $49(43)$ & $45(39)$ & $21(18)$ & $115(100)$ \\
\hline
\end{tabular}

Table 3: Frequency and location of liver abscesses in different hepatic lobes.

\begin{tabular}{|l|l|l|l|l|}
\hline Location & $\begin{array}{l}\text { Diaphragmatic } \\
\text { surface (\%) }\end{array}$ & $\begin{array}{l}\text { Visceral surface } \\
\text { (\%) }\end{array}$ & $\begin{array}{l}\text { Diaphragmatic } \\
\text { and Visceral } \\
\text { surfaces (\%) }\end{array}$ & $\begin{array}{l}\text { Diaphragmatic } \\
\text { and Visceral } \\
\text { surfaces (\%) }\end{array}$ \\
\hline Frequency & $54(47)$ & $51(44)$ & $10(9)$ & $115(100)$ \\
\hline
\end{tabular}

Table 4: Frequency and location of liver abscesses in different hepatic surfaces.

\begin{tabular}{|l|l|l|l|}
\hline Size & With abscess (\%) & Without abscess (\%) & Total (\%) \\
\hline $\mathbf{0 - 0 . 5 c m}$ & $24(4.6)$ & $498(95.4)$ & $522(10.5)$ \\
0.5-3.5cm & $206(4.6)$ & $4272((95.4)$ & $4478(89.6)$ \\
Total & 230(4.6) & 4770(95.4) & $5000(100.0)$ \\
\hline
\end{tabular}

Table 5: Frequency of liver abscess in different sizes.

\begin{tabular}{|l|l|l|l|}
\hline Number & With abscess (\%) & Without abscess (\%) & Total (\%) \\
\hline 1 or $\mathbf{2}$ & $222(4.6)$ & $4604(95.4)$ & $4826((96.52)$ \\
3or $\mathbf{4}$ & $8(4.6)$ & $166(95.4)$ & $174(3.48)$ \\
Total & $230(4.6)$ & $4770(95.4)$ & $5000(100.0)$ \\
\hline
\end{tabular}

Table 6: View a different number of liver abscesses.

frequency in diaphragmatic surfaces was $23.4 \%$ (54 cases), visceral surfaces $22.1 \%$ (51 cases), diaphragmatic and visceral surfaces $4.3 \%$ (10 cases), right lobes $21.3 \%$ (49 cases), left lobes $19.5 \%$ (45 cases), right and left lobes $9.1 \%$ (21 cases) so there was no significant difference between surfaces and lobes of livers $(\mathrm{p}>0.05)$.

\section{The number and size of the abscesses}

In this study, the size and number of liver abscess was considered. Twenty-four (10.4\%) of these hepatic abscesses had less than 0.5 $\mathrm{cm}$ diameter, with thin capsule, necrotic tissues and yellow or white suppurative contents in the central area. The rest of the examined abscesses (89.5\%) encompassed thick fibrous capsule, with central areas containing mucoid or white and yellowish-green suppurative contents, with a mean diameter of $0.5-3.5 \mathrm{~cm}$, and their number varied on all surfaces and lobes, mostly were between 1 to 5 numbers per liver, whereas among 230 abscessed livers, there were several abscesses on liver lobes, solely in 8 cases, and 222 livers had one or two abscesses (96.5\%) which 8 cases indicated three or four abscesses or more (3.4\%), so this shows there was significant difference between sizes and numbers $(\mathrm{p}<0.05)$ (Tables 5 and 6).

\section{Bacteria isolated from liver abscesses}

Aerobic and anaerobic bacteria were identified using standard procedures $[13,20]$. The abscesses were cultured for aerobic and anaerobic bacteria. The following six species of bacteria were identified: Corynebacterium spp. (120 cases, 52.4\%), Pasteurella (26 cases, 11.3\%), Escherichia coli (16 cases, 11.1\%), Proteus (16 cases, 7.2\%), Streptococcus spp. (13 cases, 5.5\%), Staphylococcus (12 cases, 5.3\%), while no agent was isolated in 2 cases. All bacterial isolates from used cultures were recorded in table 7 .

\section{Histopathology findings}

According to histopathological examination; the thick and thin 
Citation: Tehrani A, Javanbakht J, Hassan MAM, Zamani M, Rajabian M, et al. (2012) Histopathological and Bacteriological Study on Hepatic Abscesses of Herrik Sheep . J Med Microb Diagn 1:115. doi:10.4172/2161-0703.1000115

\begin{tabular}{|c|c|c|c|}
\hline $\begin{array}{l}\begin{array}{l}\text { Number of } \\
\text { Isolates (\%) }\end{array} \\
\end{array}$ & $\begin{array}{l}\text { Bacterial species iso- } \\
\text { lated }(\%)\end{array}$ & $\begin{array}{l}\text { Number of } \\
\text { Isolates (\%) }\end{array}$ & Bactria isolate \\
\hline $\begin{array}{l}42 \\
37 \\
21\end{array}$ & $\begin{array}{l}\text { C. pseudotuberculosis } \\
\text { C. pyogenes } \\
\text { C.ovis }\end{array}$ & 52.4 & Corynebacteriumspp \\
\hline $\begin{array}{l}46 \\
35 \\
19\end{array}$ & $\begin{array}{l}\text { P. haemolytica } \\
\text { P. multocida } \\
\text { P. pneumotropica }\end{array}$ & 11.3 & Pasteurellaspp \\
\hline $\begin{array}{l}39 \\
36 \\
25 \\
\end{array}$ & $\begin{array}{l}\text { P.vulgaris } \\
\text { P.mirabilis } \\
\text { P. morganii }\end{array}$ & 7.2 & Proteus spp \\
\hline \begin{tabular}{|l|}
38 \\
35 \\
27 \\
\end{tabular} & $\begin{array}{l}\text { S.pyogenes } \\
\text { S.agalatiae } \\
\text { S.dysgalactiae }\end{array}$ & 5.5 & Streptococcus spp \\
\hline \multirow[t]{3}{*}{$\begin{array}{l}56 \\
40 \\
2 \\
1 \\
1 \\
\end{array}$} & $\begin{array}{l}\text { S.epidermidis } \\
\text { S. aureus } \\
\text { S. hominis } \\
\text { S.haemolyticus } \\
\text { S. warneri }\end{array}$ & 5.3 & Staphylococcus spp \\
\hline & & 11.1 & Escherichia coli \\
\hline & & 7.2 & $\begin{array}{l}\text { Pseudomonas } \\
\text { aeruginosa }\end{array}$ \\
\hline
\end{tabular}

Table 7: Frequency of bacteria isolated from liver abscesses.

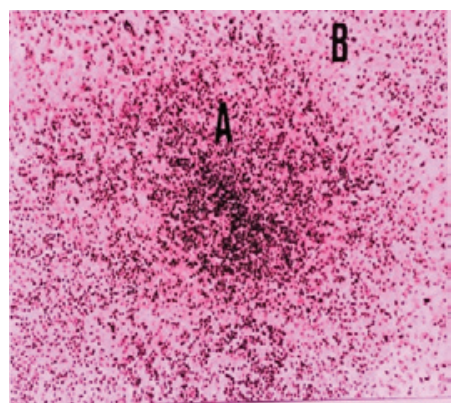

Figure 1: Liver abscess; A. Phagocytic cells, B. Liver hepatocytes.

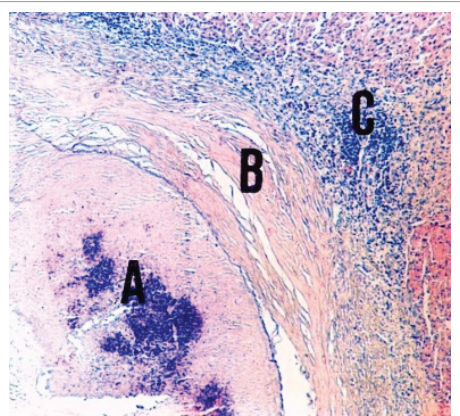

Figure 2: Liver abscess organized; A. Calcification, B. Connective tissue fibrosis, C. Inflammatory cells.

fibrous capsules were observed around abscesses, containing necrotic tissues (caseous and coagulation necrosis) that were surrounded by numerous polymorphonuclear neutrophils and some mononuclear cells. The content of these abscesses contained a purulent yellowishgreen or white, yellow and mucoid material. Sometimes, calcified centers were seen in some central areas (Figures 1 and 2).

\section{Discussions}

Although studies in several countries have reported on the incidence of sheep hepatic abscesses at abattoirs, few surveys have identified the etiology and pathological characteristics of these abscesses [21-23]. The hepatic is particularly sensitive to abscesses because it receives blood from various sources, encompassing the hepatic artery, the portal system and the umbilical vein in fetus and neonate. Entry via portal vein is most common route [7]. Jensen believed that hepatic abscess occurs in all age groups in ovine but feedlot lambs 4-6 months shows a higher prevalence rather than other age groups [20]. Out of a total of 5000 necropsied sheep, $230(4.6 \%)$ cases exhibited liver abscesses with a higher incidence in adult (80.5\%) than in young animals (19.5\%). In a study in Jordan, The incidence of liver abscesses from 2040 slaughtered sheep was estimated at about $16.5 \%$ [24], however, in another study in Texas, approximately $16.4 \%$ has been reported [2] and in a study in Ahvaz (South West of Iran), 8.6\% has been reported [11]. In the present study inabattoirs (North West and West Iran), the incidence of hepatic abscess in roughly $4.6 \%$ was reported which is lower figure rather than results of different studies. It seems to be the reason of difference between frequencies of hepatic abscesses with other studies is difference management practices and nutrition of these countries. It should be noted that although many factors are involved in occurrence of hepatic abscess, but diet is the most important one and hepatic abscesses usually occurs after receiving more carbohydrate food that results in rumenitis [25].Two major risk factors have been announced to be related with the high outbreak of hepatic abscesses in small and large ruminants. The first of these risk factors is grain overload, which causes steep decline in rumen $\mathrm{pH}$ and induces lead to atony of the rumen and damage to the rumen wall. This will give the opportunity to some of the ruminal bacteria to reach the portal vein and finally causing hepatic abscesses [25]. The other risk factor is parasite-induced damages that create appropriate environment for some opportunistic bacteria to fill and form abscesses [2]. The following bacteria were cultured from these liver abscesses: Corynebacterium pseudotuberculosis (42\%), Trueperella pyogenes (37\%), Corynebacterium ovis (21\%), Pasteurella haemolytica (46\%), Pasteurella multocida (35\%), Pasteurella pneumotropica (19\%), Escherichia coli (11.1\%), Proteus vulgaris (39\%), Proteus mirabilis (36\%), Proteus morganii (25\%), Pseudomonas aeruginosa (7.2\%), Streptococcus pyogenes (38\%), Streptococcus agalactiae (35\%), Streptococcus dysgalactiae (27\%), Staphylococcus epidermidis (56\%), Staphylococcus aureus (40\%) and other Staphylococcus (4\%). Similar bacterial isolates by Tadayon had done in 1980 in South Iran [21-23] and in Brazil by Santa Rosa et al. was isolated in 1989 as well [26]. The bacterial agents isolated from the majority of the liver abscesses were identical to those found at the other sites of infection in the same animals $[18,20]$. This finding is in accordance with those of in other domestic species. This study is the first one discusses the etiology of liver abscesses in four races sheep. We have found that liver abscesses occurred more frequently in four races sheep, and Corynebacterium pseudotuberculosis (42\%) is the most prevalent bacterial isolate. Our results are in agreement with those reported by Rosa et al. [26] in which Corynebacterium pseudotuberculosis (58.8\%) was more frequently isolated from liver abscesses from goats slaughtered in Brazil. Abscesses caused by C. pseudotuberculosis were generally extensive, including diaphragmatic and visceral surfaces and hepatic lobes. These abscesses varied in size from less than 0.5 to $3.5 \mathrm{~cm}$ in diameter and from 1 to 5 in number. Macroscopically, they appeared on the visceral or diaphragmatic hepatic surfaces. The content of these abscesses contained a purulent yellowish-green or white material. Histologically the abscesses consisted central areas of caseous necrosis surrounded by numerous polymorphonuclear neutrophils and some mononuclear cells with calcified centers. The Corynebacterium, Pasteurella species, Staphylococcus species, Streptococcus species, E. coli, Proteus species, and Pseudomonas aeruginosa were isolated from abscesses which were macroscopically alike to those associated with C. pseudotuberculosis but showed an inclination to be focally located in only one of the hepatic 
Citation: Tehrani A, Javanbakht J, Hassan MAM, Zamani M, Rajabian M, et al. (2012) Histopathological and Bacteriological Study on Hepatic Abscesses of Herrik Sheep . J Med Microb Diagn 1:115. doi:10.4172/2161-0703.1000115

Page 4 of 4

lobes on either visceral or diaphragmatic surfaces and varied in size from 0.5 to $2 \mathrm{~cm}$ while numbering only 1 to 3 . The content of the abscesses was yellow or white. Histologically there was a central area of coagulative necrosis with cell infiltrates similar to those observed in abscesses, caused by C. pseudotuberculosis. Furthermore, in this study observation of more abscesses on diaphragmatic and visceral surfaces of hepatic can be due to more exposure of these parts to portal vein blood flow. According to the results of this study and comparison with incidence of liver abscess in cattle, goats and sheep in Jordan, Brazil, Ahvaz and a survey in South Iran by Tadayon [23], it seems that frequency of hepatic abscesses in sheep in is not high in these districts.

\section{Acknowledgment}

The authors thank staff of the Department of Pathology, Faculty of Veterinary Medicine, Urmia University for their valuable technical assistance.

\section{References}

1. Lechtenberg KF, Nagaraja TG, Leipold HW (1988) Bacteriologic and histologic studies of hepatic abscesses in cattle. Am J Vet Res 49: 58-62.

2. Scanlan CM, Edwards JF (1990) Bacteriologic and pathologic studies of hepatic lesions in sheep. Am J Vet Res 51: 363-366.

3. Berg JN, Scanlan CM (1982) Studies of Fusobacterium necrophorum from bovine hepatic abscesses: biotypes, quantitation, virulence, and antibiotic susceptibility. Am J Vet Res 43: 1580-1586.

4. Simon PC, Stovell PL (1971) Isolation of Sphaerophorus necrophorus from bovine hepatic abscesses in British Columbia. Can J Comp Med 35: 103-106.

5. Marsh $\mathrm{H}(2000)$ Necrobacillosis of the rumen in young lambs. J Am Vet Med Assoc 104: 23-25.

6. Fetcher A (1983) Liver diseases of sheep and goats. Vet Clin North Am Large Anim Pract 5: 525-525.

7. Nagaraja TG, Chengappa MM (1998) Liver abscesses in feedlot cattle: a review. J Anim Sci 76: 287-298.

8. Navarre CB, Pugh DG (2002) Disease of the Liver: Sheep and Goat Medicine. Pug DG (Ed.) (1stedn), W.B. Saunders, Philadelphia 97-104.

9. Nagaraja TG, Beharaka AB, Chengappa MM, Carroll LH, Raun AP, et al. (1996) Liver abscesses in feedlot cattle. Compend Cont Educ 18: 230-241.

10. Jacob C (1981) General Practice 17: 105

11. Ghadrdan-Mashhadi A, Gorban-Poor M, Soleimani M (2006) Bacteriological Study of Liver Abscesses in Sheep in Ahvaz (Iran). Pak J Biol Sci 9: 2161-2164

12. Diskuel N, Baldwin B, Bromel MC (1978) Annual Meeting of the American Society of Microbiology 78: 325

13. Kanoe M, Imagnwa H, Mitsuyushi T (2004) Japanese Journal Veterinary Science 38: 263.

14. Kanoe M, Yuji I, Masayuki K (2002) Japanese Journal Veterinary Science 41 : 73.

15. Araghi-Sooreh A, Firuzi M (2011) A bacteriologic study on hepatic abscesses of goats slaughtered at the Urmia abattoir.

16. Carter GR, Cole JR (1990) Diagnostic procedures in veterinary bacteriology and mycology. (4thedn), Charles C. Thomas, Springfield, Illinois, USA 3-166.

17. Lennette EH, Balows A, Hausler WJ (1985) Clinical Microbiology. American Society for Microbiology, Washington, DC.

18. Winter H (2009) In: Guiapara la. Necropsia de los Rum nantes Domesticos, Philadelphia.

19. Luna LG (1968) In Manual of Histological Staining Methods of the Armed Forces Institute of Pathology. (3rdedn), New York: McGraw Hill.

20. Jensen R (1974) Disease of Sheep. Lea and Febiger, Philadelphia.

21. Antia RE, Alonge DO (1982) Survey of abattoir data in Southern Nigeria. Trop Anim Health Prod 14: 119-120.

22. Blamire RV, Goodhand RH, Taylor KC (1980) A review of some animal diseases encountered at meat inspections in England and Wales, 1969 to 1978. Vet Rec 106: 195-199.

23. Tadayon RA, Cheema AH, Muhammed SI (1980) Microorganisms associated with abscesses of sheep and goats in the south of Iran. Am J Vet Res 41 798-802.

24. Al-Qudah K, Al-Majali A (2003) Bacteriologic studies of liver abscesses of awassi sheep in Jordan. Small Ruminant Research 47: 249-253.

25. Radostits OM, Blood DC, Gay CC, Hinchcliff KW (2000) Veterinary Medicine. (9thedn), WB Saunders, China.

26. Rosa JS, Johnson EH, Alves FS, Santos LF (1989) A retrospective study of hepatic abscesses in goats: pathological and microbiological findings. $\mathrm{Br}$ Vet J 145:73-76. 